\title{
INVESTIGATING THE DYNAMICS OF AN INVENTORY SYSTEM IN THE MANUFACTURING SECTOR: A CASE STUDY
}

\author{
M.K.O. Ayomoh ${ }^{1}$, O. Oladeji ${ }^{2}$ and S.A. Oke ${ }^{3}$ \\ ${ }^{1,3}$ Department of Mechanical Engineering \\ University of Lagos, Nigeria \\ 1․mikeayomoh@yahoo.com, ${ }^{3}$ corresponding author: sa_oke@yahoo.com \\ ${ }^{2}$ Department of Industrial and Production Engineering \\ University of Ibadan, Nigeria \\ oye_oladeji@yahoo.com
}

\begin{abstract}
Research on inventory systems has steadily increased over the past several decades as professionals seek to optimise the limited resources associated with inventory management. Recently, an international automobile windscreen manufacturing plant in Nigeria that is facing intense international competition has sought to improve its operational efficiency and profitability. The management has considered system reengineering as a viable option. Hence, all the functional units in the organisation have to be transformed. This has stimulated the present study on inventory. The study proposes a classic industrial engineering methodology in quantifying the balance between holding too much and too little inventory. In particular, industrial dynamics is used as a method of analysis. Improved cost figures are reported on the existing system.
\end{abstract}

\section{OPSOMMING}

Gedurende die afgelope dekades was daar 'n toename in navorsing oor die optimisering van beperkte bronne vir voorraadsisteme. Onlangs het 'n Nigeriese internasionale windskermvervaardiger gepoog om die doeltreffendheid en winsgewendheid van hulle onderneming te verhoog teen 'n agtergrond van intense internasionale mededinging. Om dit te bereik, het die onderneming besluit om te herorganiseer en al die funksionele produksieeenhede te transformeer. Sodoende is die voorraadvraagstuk ook onder die loep geneem. Die navorsing het gevolglik voorraadhou en -tekortekoste bestudeer as 'n dinamiese verskynsel. Hiervoor is betroubare praktykgegewens en die welbekende Industriedinamika gebruik as die ontledingsmetode. Die navorsing het verbeterde kosteresultate bewerkstellig. 


\section{INTRODUCTION}

Investigations in inventory management have undergone tremendous development over the past several decades $[1,3,5,8,11,13,15]$. The percentage of studies on interface issues continually increases as a result of the advancement in computer technology. The impact of computers on inventory systems modelling is complex and multifaceted. On the surface, it bears some similarity to an appraisal of the audience in a movie theatre. A theatre can be judged to be half-full or half-empty depending upon the perspective of the perceiver. By the same token, the impact of the computer on inventory systems can be judged to be considerable if one takes into account the multiple manipulations of data which electronic data processing makes possible and performable. Data analysis in inventory systems would be all but impossible today without computers as seen in the complexity of simulation experimentation [20, 25, 27, 28]. Practitioners rely on the computer as an important and powerful tool for collecting, recording, retrieving and analysing simple and complex problems, as well as distributing tremendous masses of information in inventory systems. It saves countless years of tedious work by inventory experts. The computer removes the necessity for men to monitor and control tedious and repetitive processes.

Computer simulation provides an effective pragmatic approach to detailed analysis and evaluation of supply chain management. However, the usefulness of this methodology is hampered by the time and effort required to develop models with sufficient fidelity to the actual supply chain of interest [4, 10, 11, 21, 23, 24]. The dynamic model of the system could be used to evaluate changes in given policies in any one segment of the total process and the impact of these changes is evaluated by the simulated operating results. This technique gives an opportunity to test and evaluate proposals without running the risk of actually installing new approaches and absorbing the necessary costs associated with system changes.

Consequently, by combining the powerful potential of computer technology with some novel approaches to system modelling, a research stream that investigates the improvement of inventory systems in manufacturing emerges [19, 25, 28]. This domain of knowledge is the central focus of this work. This work presents a dynamic simulation model [2, 9, 22] that was used to study the behaviour of raw materials and finished goods in a manufacturing system. The conceptual approach also incorporated the distributors' inventory systems. This forms the traditional production-distribution perspective of analysing inventory problems $[6,7,12,14$, $16,17,26]$.

As a result, a case was demonstrated to show how our model could aid in proposing a set of changes to the inventory policies. Specifically, we investigated the ordering of raw materials and finished goods, as well as the production of finished goods, using the holistic concept of system analysis [18]. Emphasis was placed on the factory and distribution centres such that neither stockout nor excessive inventory results. Here, the dynamic behaviour of market demand throughout the horizon period of 210 weeks was considered.

This objective was achieved through the development of a set of dynamic equations of the system studied. Simulation experimentation of the current operational policies was carried out to identify the limitations and problems of the current policies. 


\section{MODEL FORMULATION AND VALIDATION}

The formulation of the model was viewed from three perspectives viz.: production, distribution, and consumption. Our discussion is based on the system dynamic perspective following the holistic approach. It is assumed that: (i) the consumption rate is controlled by exogenous variables outside the boundary of the system; (ii) no information delays in production or placement of orders are observed. However, materials delay is recognised in production, ordering of goods, and raw materials; (iii) all inventory holding costs, $\mathrm{C}_{\mathrm{h}}$, are ranged within the values shown in the inequality of $0.7 \mathrm{p}<\mathrm{C}_{\mathrm{h}}<7 \mathrm{p}$ per unit of item; and (iv) the factory works six days per week.

\begin{tabular}{|c|c|c|c|}
\hline Quantity & Description & Classification & Units \\
\hline AROGS & Arrive Rate of Glass Sheets & Variable & Units/Time \\
\hline IOR & Interlayer Ordering Rate & Variable & Units/Time \\
\hline PR & Production Rate & Variable & Units/Time \\
\hline DOR & Distributors' Ordering Rate & Variable & Units/Time \\
\hline AROFG & Arrive Rate of Finished Goods & Variable & Units/Time \\
\hline CR & Consumption Rate & Variable & Units/Time \\
\hline GSOT & Glass Sheet Ordering Time & Variable & Time \\
\hline DOGS & Delay Ordering Glass Sheet & Variable & Time \\
\hline IOT & Interlayer Ordering Time & Parameter & Time \\
\hline FIAT & Finished goods Inventory Adjustment Time & Parameter & Time \\
\hline DOT & Distributors' Ordering Time & Parameter & Time \\
\hline ODOFG & Order Delay of Finished Goods & Variable & Time \\
\hline PGSDINV & Processed Glass Sheet Desired Inventory & Variable & Units \\
\hline PGSDSCR & Processed Glass Sheet Discrepancy & Variable & Units \\
\hline PGSINV & Processed Glass Sheet Inventory & Variable & Units \\
\hline RGSINV & Raw Glass Sheet Inventory & Variable & Units \\
\hline IIEOP & Interlayer Inventory Equivalent Of Production & Variable & Units \\
\hline GSIEOP & Glass Sheet Inventory Equivalent of Production & Variable & Units \\
\hline PTGSIR & Production To Glass Sheet Inventory Ratio & Parameter & Dimensionless \\
\hline PTIIR & Production To Interlayer Inventory Ratio & Parameter & Dimensionless \\
\hline INVOGI & Inventory Of Glasses Interlayer & Variable & Units \\
\hline IINV & Interlayer Inventory & Variable & Units \\
\hline IGDISCR & Interlayer Glass Discrepancy & Variable & Units \\
\hline DINVOGI & Desired Inventory Of Glasses interlayer & Variable & Units \\
\hline FINV & Finished goods Inventory & Variable & Units \\
\hline DFINV & Desired Finished Goods Inventory & Variable & Units \\
\hline FDISCR & Finished Goods Discrepancy & Variable & Units \\
\hline DINV & Distributors' Inventory & Variable & Units \\
\hline DDISCR & Distributors' Discrepancy & Variable & Units \\
\hline DDINV & Desired Distributors' Inventory & Variable & Units \\
\hline MULT & Desired Inventory Multiplier Factor & Variable & Dimension less \\
\hline
\end{tabular}

Table 1: Model variables and parameters

From the causal diagram of the system, the inter-relationship among the components and the extent to which the effect of changes in the behaviour of one affects the other were reflected. As a result, a flow chart of the components was drawn. A set of dynamic equations was developed from the flow chart for both the initial and improved systems. These are shown in the appendix. In solving this problem, the dynamo computer simulation software was applied. 
Figures 1 and 2 show the causal loop and flow charts for the improved system while table 1 contains a description of the model variables and parameters.

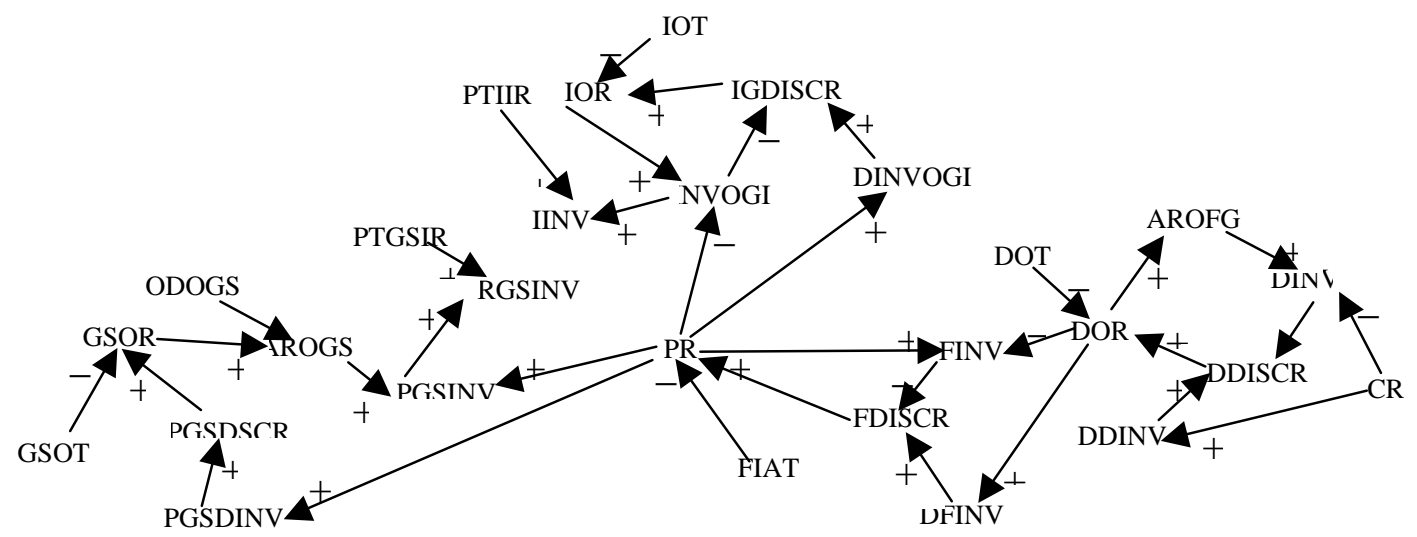

Figure 1: Causal loop diagram

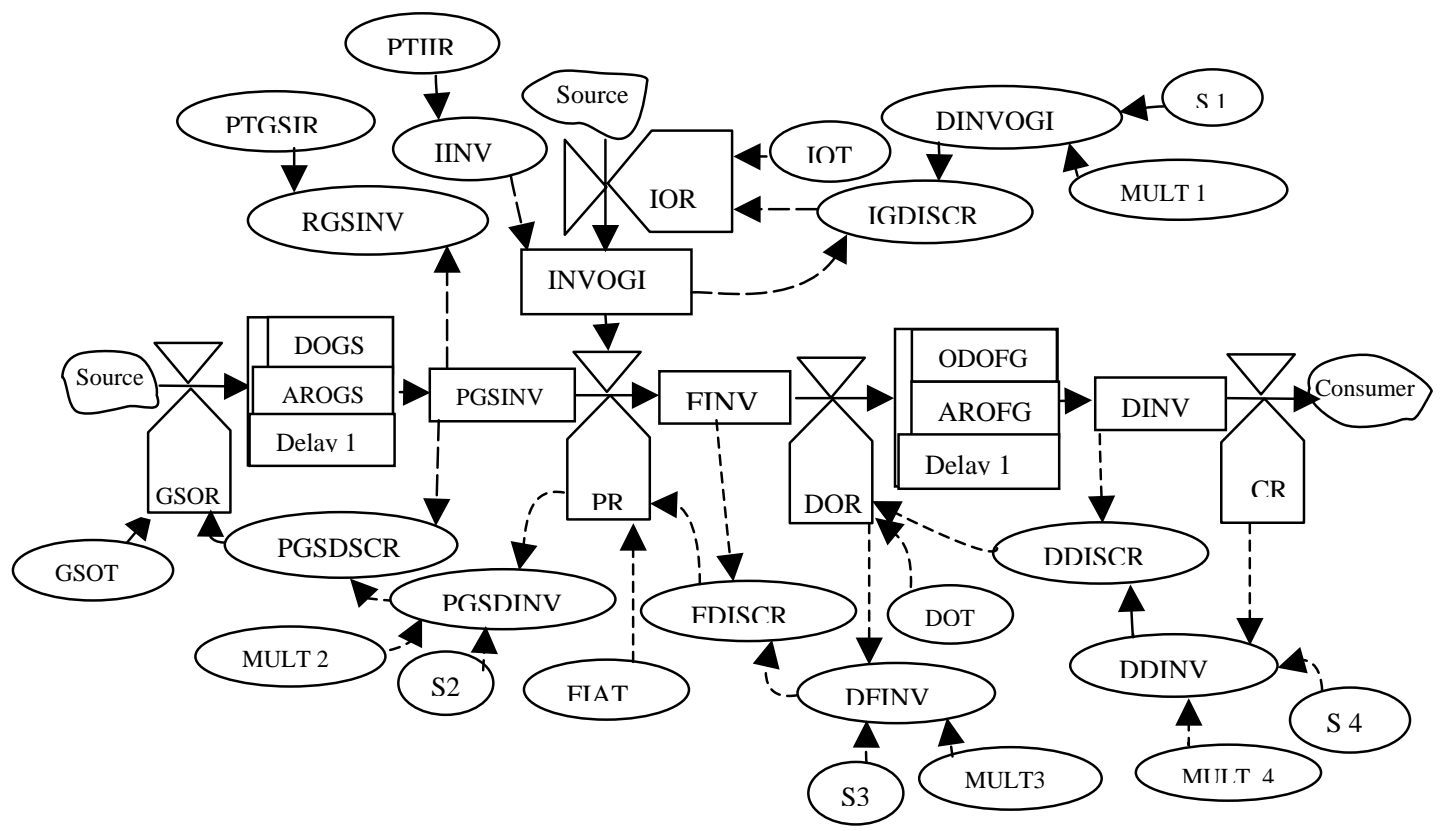

Figure 2: Flow chart for improved system

The set of data obtained could be classified into ordering, production and consumption. This covered the raw materials and finished products for the factory and distributing centres. Also covered is the customers' consumption pattern. All of these are shown in table 2. 


\section{MODEL SIMULATION}

This section contains the analysis of the model experimentation. Two different simulation trials were conducted viz.: (i) the initial system simulation, and (ii) the improved system simulation. Each trial has four different graphical plots representing the following variables: RGSINV and GSOR, IINV and IOR, DINV and DOR, also FINV and PR. The set of data described above was obtained from an automobile windscreen manufacturing industry. They were used to study the structure and behaviour of the initial system. The data applications could be seen as applied only in the dynamic equations as shown in appendix 1, which represents the initial system. The outcomes of the simulation are discussed with respect to the initial and improved systems.

\begin{tabular}{|c|c|c|c|c|c|}
\hline & $\begin{array}{c}\text { Raw } \\
\text { material } \\
\text { (Ouantity) }\end{array}$ & $\begin{array}{l}\text { Finished } \\
\text { goods }\end{array}$ & & & \\
\hline Months & Interlayer & Glass sheet & $\begin{array}{l}\text { Factories' } \\
\text { Inventory }\end{array}$ & $\begin{array}{l}\text { Distributors' } \\
\text { Inventory }\end{array}$ & $\begin{array}{c}\text { Customers' } \\
\text { demand }\end{array}$ \\
\hline Jan. 2001 & & 1600 & & 3852 & 1000 \\
\hline Feb. 2001 & & & & 3296 & 850 \\
\hline March 2001 & 34 & & & 2734 & 700 \\
\hline April 2001 & & & & 3119 & 565 \\
\hline May 2001 & 28 & 456 & 2286 & 5742 & 780 \\
\hline June 2001 & 14 & 1368 & 3418 & 4014 & 1440 \\
\hline July 2001 & 9 & & 3078 & 4755 & 1050 \\
\hline Aug 2001 & & & 3121 & 3216 & 1200 \\
\hline Sep 2001 & 16 & & 3116 & 2485 & 1100 \\
\hline Oct 2001 & & & 2439 & 2395 & 810 \\
\hline Nov 2001 & 27 & & 1223 & 2401 & 600 \\
\hline Dec 2001 & & & 2555 & 1000 & 625 \\
\hline Jan 2002 & 28 & 912 & 1669 & 1396 & 1200 \\
\hline Feb 2002 & & 124 & 583 & 2698 & 1030 \\
\hline March 2002 & & 124 & 3326 & 5400 & 300 \\
\hline April 2002 & 36 & 128 & 445 & 4112 & 400 \\
\hline May 2002 & & 64 & 2326 & 2400 & 780 \\
\hline June 2002 & 29 & 1368 & 1316 & 1867 & 1350 \\
\hline July 2002 & & & 622 & 1590 & 500 \\
\hline Aug 2002 & 9 & 148 & 2684 & 2435 & 600 \\
\hline Sep 2002 & & 62 & 1345 & 1878 & 810 \\
\hline Oct 2002 & 12 & 62 & 1066 & 110 & 600 \\
\hline Nov 2002 & & 128 & 1066 & 1867 & 650 \\
\hline Dec 2002 & & 128 & 1454 & 2000 & 500 \\
\hline Jan 2003 & 19 & 128 & 1121 & 1396 & 500 \\
\hline Feb 2003 & 15 & & 1454 & 2435 & 650 \\
\hline Mar. 2003 & 20 & 128 & 1121 & 1878 & 470 \\
\hline April 2003 & 15 & & 884 & 1100 & 275 \\
\hline
\end{tabular}

Table 2: Finished goods and raw materials characteristics data (2001-2003) 


\section{Initial system behaviour}

For the simulated quantities for the initial system behaviour (namely: RGSINV and GSOR, IINV and IOR, DINV and DOR, also FINV and PR respectively), the inventory levels continued in an exponential decay throughout the period considered. The RGSINV, with an initial level of 1600 units experienced stockout in the $12^{\text {th }}$ week with a value of $-61,77$ units and continued to decay exponentially. The IINV commenced with an inventory level of 30 units, continued in its deterioration until stockout set in on the $34^{\text {th }}$ week with a value of 0,91368 units. This deterioration continued throughout the horizon period. The case with the FINV was quite similar to IINV. With an initial inventory level of 300 units, stockout was experienced in the $39^{\text {th }}$ week with a value of $-346,7$ units. A period of growth and decline of inventory was experienced throughout the horizon period.

The DINV had an initial inventory level of 5550 units in the first week. A peculiar experience cropped up here as the inventory appreciated significantly in the $23^{\text {rd }}$ week, having suffered a significant exponential decay earlier. This growth reached a peak value of $12,34 \mathrm{x}$ $10^{3}$ units in the $47^{\text {th }}$ week. After this, a period of inventory undulation occurred until stockout was experienced in the $117^{\text {th }}$ week with a value of $-23,143$ units. This stockout situation continued until the end of the horizon period.

\section{Improved system behaviour}

The simulated quantities for the improved system (i.e. RGSINV and GSOR, IINV and IOR, FINV and PR, also DINV and DOR) show that the obvious characteristic of the associated inventories is sigmoid. There is an inventory decline in several instances within the horizon period. However, a situation of stockout or negative inventory was completely eliminated. A set of dynamic equations was used to simulate the improved system (see appendix 2).

This was obtained by varying the multiplier factor for all desired inventories until a stockout situation was completely eliminated from the system to attain system improvement. For DIINV, the MULT at which no negative inventory occurred was attained at 19,6 while PGSDINV had a minimum MULT of 17,4. Finally, DFINV and DDINV had their MULTs as 6,1 and 5,6 respectively. By interpretation, it means that DIINV must be at least 19,6 times the current PR. Also, PGSDINV must be at least 17,4 times the current PR, and DFINV must be at least 6,1 times the current DOR and lastly, DDINV must be at least 5,6 times the current CR for a system void of stockout to be attained. This considers the management inventory policy governing the inventory system.

\section{COST ANALYSIS OF INITIAL AND IMPROVED SYSTEMS}

The cost analysis compares the total inventory costs associated with both the initial and improved systems within the horizon period considered. The cost variables considered are those directly associated with the simulation experimentation namely: (i) the inventory holding cost and (ii) the stockout or shortage cost. On the simulation graphs, plots below zero indicate shortage while plots above zero indicate inventory at hand. It is desired to quantify in monetary terms the cost of not having finished goods to fill orders or satisfy demand.

Also required is the cost of holding extra finished goods after orders and demands have been 
satisfied. The cost analysis is considered for both the factory and the distributing centres. The cost analysis is aimed at helping management to see the merits of the improved system.

\section{Notations for the cost analysis}

The following notations are used in the cost analysis:

$\mathrm{Q}_{\mathrm{h}}=$ Inventory at hand after satisfying demand.

$\mathrm{Q}_{\mathrm{s}}=$ Inventory stockout quantity.

$\mathrm{C}_{\mathrm{h}}=$ Cost of carrying or holding a unit of finished product.

$\mathrm{C}_{\mathrm{s}}=$ Average selling price of a unit of finished product.

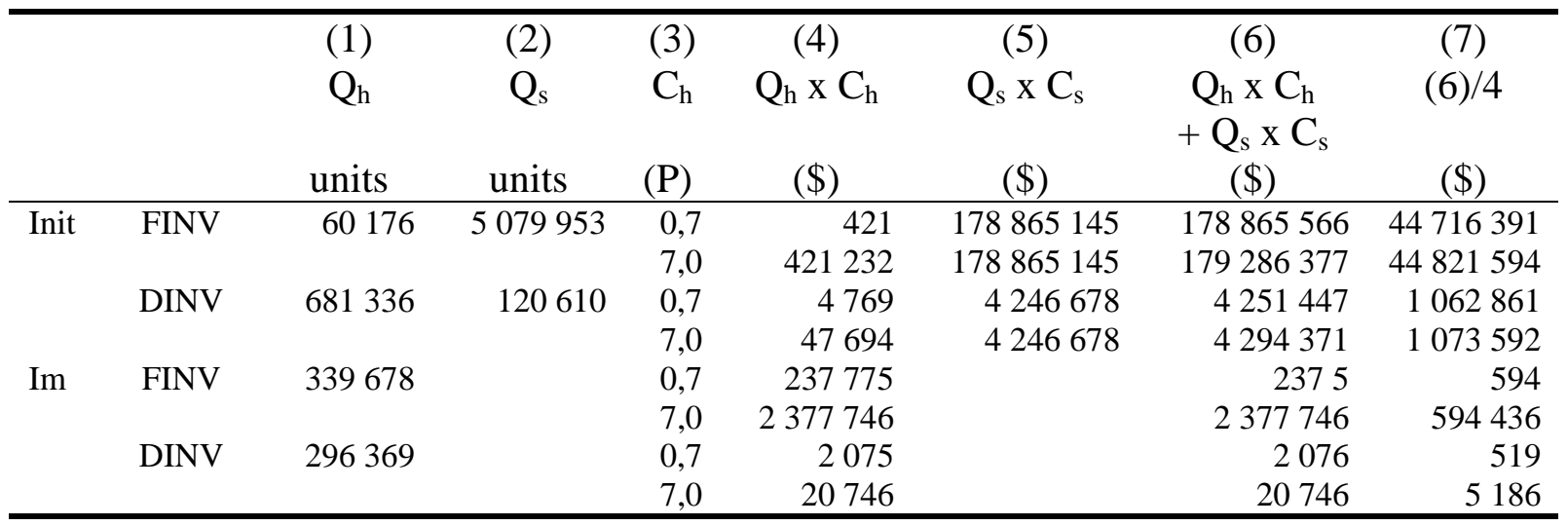

Table 3: Inventory cost analysis

The quantity or level of stockout/inventory was determined using the simulation graphs. This was done by evaluating the area enclosed between the curves and the axial line for the $\mathrm{x}$-axis. A breakdown of the cost analysis for both the initial and improved systems is shown in table 3. The assumption considered for $\mathrm{C}_{\mathrm{h}}$ as earlier stated is used in the analysis in order to have a clear view of the probable range of cost. The value for $\mathrm{Q}_{\mathrm{s}}$ was taken as \$35,21.This represents the selling price per unit product or the cost of a unit shortage or stockout. It was assumed to be equal for both the factory and distributing centres.

The eventual outcomes as shown in the table strongly indicate that the improved system, if implemented would be of a significant financial benefit to the production system. From column 7 of the cost analysis table, total estimates of \$44 821594 and \$1 073592 were realised within the limits of the holding cost assumption, as maximum cost incurrable annually. The values \$44 716391 and \$1 062861 were attributed to the cost incurrable annually for the lowest value of the holding cost range. These are cost values for both the factory and distributing centres respectively for the initial system behaviour.

The improved system is characterised with the values \$594 436 and \$5 186 as annual cost for the highest value of the holding cost range while the values \$594 and \$519 are incurrable costs for the lowest value of the holding cost range. These are also annual costs incurrable by the factory and distributing centres respectively. 


\section{CONCLUDING REMARKS}

The focus of the paper was to propose a classic industrial engineering methodology in quantifying the balance between holding too much and too little inventory. This is in response to the enormous pressure placed on an automobile windscreen manufacturing plant to improve business efficiency and profitability. We presented a method of analysis based on industrial dynamics principles with a rigorous test using practical data. In particular, we propose a simulation model that could be used to study the structure and behaviour of the system. This was preceded by the development of a causal loop diagram, which metamorphosed into a flow chart, from which a set of dynamic situations was derived and used in the simulation process.

The improved cost figures that the article reports on rely on the manipulation of historical data. Simulation runs were conducted in validating the model for the improved system behaviour with respect to the objective. This is to ensure that no stockout was observed throughout the horizon period considered.

Clearly, this work has some practical implications for industrial engineering practice. For example, the typical inventory manager operates in an awkward situation, where he seldom has the necessary information to show the true inventory alternatives to his management, in order to assist them in making policy. This work therefore presents a decision-making tool and aid towards achieving progress in inventory management. Therefore, setting some arbitrary inventory policies may be avoided with the introduction of scientific principles. Overall, the work has implications for the inventory policy with respect to striking a balance between customer service and inventory investment. The indirect implication of this work is influenced by what the setup and ordering cost of inventory investment will be.

This article has attempted to add to the development of a case study approach to investigating a manufacturing system with the use of the classical system dynamics methodology. This methodology, as applied here, is still in its infancy. There are many more steps in the process that could not possibly be dealt with in the scope of an article. For example, because the methodology is critically dependent on the arrival and ordering rates of raw materials, the need to conceptualise these two parameters from a scientific perspective is important. If this is successful, future modellers could integrate these components in such a way that they will predict the inventory system behaviour in a wide range of circumstances.

Another interesting dimension of this work is to consider the behaviour of both the arrival and ordering rates of raw materials in two different environments. The case of a just-in-time (JIT) system and the supply/delivery systems with lead-time may be interesting to understand. Other future research projects may include (i) studying the behaviour of the in-process inventory and the impact of its accumulation rate on the finished goods, production rate, and raw material depletion rate; (ii) determining the rate at which defective products are accumulated during each day's production run and measures by which they could be minimised; and (iii) developing a model to minimise scrap collection while cutting the raw glass sheets to desired shapes.

Further work could for example investigate the effect of reduced setup costs on inventory levels and the level of inventory required to give any desired level of customer service, etc. 


\section{ACKNOWLEDGEMENT}

The authors gratefully acknowledge the constructive criticisms of the anonymous referees who reviewed this work.

\section{REFERENCES}

[1] Agholor, D.I. (1995). Development of a system dynamics model of the inventory system of a battery manufacturing company. An unpublished M.Sc. Thesis, Department of Industrial and Production Engineering, University of Ibadan, Nigeria.

[2] Agrell, P.J. and Wikner, J. (1996), An MCDM framework for dynamic systems, International Journal of Production Economics 45:279-292.

[3] Arreola-Risa, A. (1996). Integrated Multi-item production inventory systems. European Journal of Operational Research 89:326-340.

[4] Berry, D and Towell, D. R., (1996). Quantifying the relative improvement of redesign strategies in a P.C. supply chain. International Journal of Production Economics 46-47: 181-196.

[5] Bonney, M.C. (1994). Trends in inventory management. International Journal of Production Economics 35: 107-114

[6] Chandra, P., and Fisher, M.L. (1994). Coordination of production and distribution planning, European Journal of Operational Research, 72, 503-517.

[7] Emeribe, O.P. (1998). Effective strategy for the redesign of production-distribution system: A system dynamics approach using control engineering techniques, An Unpublished M.Sc Thesis, Industrial and Production Engineering Department, University of Ibadan, Nigeria.

[8] Everett, E., Adam, Jr. and Ronald, J.E. (1992). Production and operations management, fifth edition. Prentice hall India.

[9] Forrester, J.W. (1961). Industrial dynamics. Cambridge MA: Production press.

[10] Hafeez, K., Graffths, J. and Naim, M.M. (1996). System design of a two-echelon steel industry supply chain, International Journal of Production Economics 45: 121-130.

[11] Hariga, M.A. Economic analysis of dynamic Inventory models with non-stationary costs and demand. Int. J. Production Economics 36: (1994) 255-266.

[12] Jackson, P.L., Maxwell, W.L. and Muckstadt, J.A. (1998). Determining Optimal Reorder intervals in Capacitated Production-Distribution Systems. Management Science, 34(8), 938-958.

[13] Muckstadt, J.A., D.H. Murray and J.A. Rappold. (2001). Capacitated production planning and inventory control when demand is unpredictable for most items: The No $\mathrm{B} / \mathrm{C}$ strategy, under review.

[14] Olsmats, C.M.G., Edghill, J.S. and Towill, D.R.(1988). Industrial dynamics model building of a close-coupled production-distribution, System. Engineering Cost and Production Economy 13:295-310.

[15] Potamianos, J., Orman, A.J., and A.K. Shahani. (1997). Modelling for a dynamic Inventory-Production control system. European Journal of Operational Research, 96,645-658.

[16] Pyke, D.F., and Cohen, M.A. (1993), Performance characteristics of stochastic integrated production-distribution systems, European Journal of Operational Research, 68, 23-48. 
[17] Rappold, J. A. and Muckstadt, J. A. (2000), A computationally efficient approach for determining safety levels in a capacitated multi-echelon production-distribution system. Naval Research Logistics, 47(5): 377-398.

[18] Sage, A.P. (1980), Methodology of large-scale systems, Beverly Hill Sage Publication, London.

[19] Sarmiento, A.M. and Nagi, R. (1999), Recent directions in integrated analysis of manufacturing-distribution systems, IIE Transactions on Scheduling and Logistics, Special Issue on Manufacturing Logistics, Vol. 31(11): pp. 1061-1074.

[20] Satya, S.C. (1992), A simulation study of the performance of a multi-echelon production-distribution system with feedback and feed forward controls, (Chair Blackstone), <www.goldratt.com/phdabstracts>.

[21] Shapiro, Jeremy F. (2001), Modelling the supply chain, Duxbury Press, Pacific Grove, California.

[22] Spector, J. M. and Davidsen, P. I. (1998), Constructing learning environments using system dynamics, Journal of Courseware Engineering, Vol. 1, pp. 5-11.

[23] Swaminathan, J. M., Smith, S.F. and Sadeh, N.M. (1995). Modeling the dynamics of supply chains, The Robotics Institute Carnegie Mellon University, Pittsburgh, Pennsylvania.

[24] Swaminathan, J. M., Smith, S.F. and Sadeh, N.M.(1998). Modelling supply chain dynamics: a multiagent approach, Decision Sciences, Vol.29 (3): pp. 607-632

[25] Travis, A.D. and Brian, F. J. (2000). Confident Decision Making and Improved Throughput for Cereal Manufacturing with Simulation. Winter Simulation Conference Final Program Abstracts Manufacturing Applications Track.

[26] Vidal, C. J. and Goetschaichx, M. (1996), Strategic Production-Distribution Models: A critical Review with Emphasis on Global Supply Chain Models. Centre for international Business Education and Research (GT CIBER). Working Paper Series 1996/96022.

[27] White Paper (2002). Dynamic simulation and supply chain management, Available on line via http://www.goldsim.com.

[28] Williams, A. and Davidson, J. (1998), The use of simulation techniques to evaluate manufacturing strategies: a case study in the application of data capture prior to simulation. The $15^{\text {th }}$ International Conference on Production Research (ICPR-15 manufacturing for a global market). pp. 1397-1400.

\section{APPENDIX 1}

\section{DYNAMO PROGRAMME FOR INITIAL SYSTEM BEHAVIOUR NOTE INTERLAYER INVENTORY SUB-SECTION}

\footnotetext{
L INVOGI.K=INVOGI.J+DT*(IOR.JK-PR.JK) INVENTORY OF GLASSES INTERLAYED (UNITS)

$\mathrm{N}$ INVOGI=INVOGII INITIAL INVENTORY FOR INTERLAYED GLASSES (UNITS)

C INVOGII $=4500$

C PTIIR=150 PRODUCTION TO INTERLAYER INVENTORY RATIO (DIMENSIONLESS)

A IINV.K=INVOGI.K/PTIIR INTERLAYER RAW MATERIAL INVENTORY (UNITS)

R IOR.KL=MAX (IIEOP.K/IOT.K,0) INTERLAYER ORDERING RATE (UNITS/WEEK)

A IIEOP.K=IOQ.K*PTIIR INTERLAYER INVENTORY EQUIVALENT OF PRODUCTION (UNITS)

A IOQ.K= TABLE(TIOQ,TIME.K,0,210,15) TABLE FOR INTERLAYER ORDERING QUANTITY (UNITS)

T TIOQ=34/28/14/9/16/27/28/36/29/9/12/19/15/20/15

A IOT.K=TABLE (TIOT, TIME.K, $0,210,15$ ) TABLE FOR INTERLAYER ORDERING TIME (WEEKS)

T TIOT $=16 / 3 / 6 / 10 / 12 / 17 / 14 / 10 / 12 / 14 / 19 / 4 / 8 / 10 / 12$

NOTE **GLASS SHEET SUB-SECTION**

L PGSINV.K=PGSINV.J+DT*(AROGS.JK-PR.JK) PROCESSED GLASS SHEET INVENTORY (UNITS)

N PGSINV=PGSINVI

C $\mathrm{PGSINVI=4800}$
} 
C PTGSIR=3 PRODUCTION TO GLASS SHEET INVENTORY RATIO (DIMENSIONLESS)

A RGSINV.K=PGSINV.K/PTGSIR RAW GLASS SHEET INVENTORY (UNITS)

R GSOR.KL=MAX (GSIEOP.K/GSOT.K, 0) GLASS SHEET ORDERING RATE (UNITS/WEEK)

A GSOQ.K=TABLE (TGSOQ,TIME.K, 0, 210, 10)

T GSOQ=1600/456/1368/640/136/912/912/124/124/128/64/1368/62/148/62/62 /128/128/128/128/128/32

A GSIEOP.K=GSOQ.K*PTGSIR GLASS SHEET INVENTORY EQUIVALENT OF PRODUCTION (UNITS)

A GSOT.K=TABLE (TGSOT,TIME.K, 0, 210, 15) TABLE FOR GLASS SHEET ORDERING TIME (WEEKS)

T TGSOT=14/2/24/6/6/4/3/4/8/2/5/4/6/11/5

R AROGS.KL=DELAY1 (GSOR.KL,DOGS.K) ARRIVAL RATE OF GLASS SHEETS (UNITS/WEEK)

A DOGS.K=TABLE(TDOGS,TIME.K,0,210,30) DELAY ORDERING GLASS SHEETS (WEEKS)

$\mathrm{T}$ TDOGS $=4 / 3.5 / 3 / 2.5 / 2 / 1.5 / 1.2 / 1 \quad$ TABLE FOR DELAY ORDERING GLASS SHEETS

NOTE**FINISHED GOODS INVENTORY SUB-SECTION**

L FINV.K=FINV.J+DT*(PR.JK-DOR.JK) FINISHED GOODS INVENTORY (UNITS)

N FINV=FINVI INITIAL FINISHED GOODS INVENTORY(UNITS)

C FINVI $=3000$

C FIAT $=4$ FINISHED GOODS INVENTORY ADJUSTMENT TIME (WEEK)

R PR.KL=MAX (PQ.K/FIAT,0) PRODUCTION RATE (UNITS/WEEK)

A PQ.K=TABLE (TPQ, TIME.K, 0, 210, 10)

T $\quad P Q=2286 / 3418 / 3078 / 3121 / 3116 / 2439 / 1223 / 2555 / 1669 / 583 / 3326 / 445 / 2326 / 1316 / 622 / 2684 / 1345 / 1066 / 1066 / 1454 / 1121 / 884$

NOTE **DISTRIBUTORS INVENTORY SUB-SECTION**

L DINV.K=DINV.J+DT*(AROFG.JK-CR.JK) DISTRIBUTORS`INVENTORY (UNITS)

N DINV=DINVI DISTRIBUTORS`INITIAL INVENTORY (UNITS)

C DINVI $=5550$

C DOT $=4$ DISTRIBUTORS` ORDERING TIME (WEEKS)

R DOR.KL=MAX (DOQ.K/DOT,0) DISTRIBUTORS`ORDERING RATE (UNITS/WEEK)

A DOQ.K=TABLE (TDOQ,TIME.K,0,210,10)

T DOQ $=3852 / 3296 / 2734 / 3119 / 5742 / 4014 / 4755 / 3216 / 2485 / 2395 / 2401 / 1000 / 1396 / 2698 / 5400 / 4112 / 2400 / 1867 /$ $1590 / 2435 / 1878 / 1100$

R AROFG.KL=DELAY1(DOR.KL,ODOFG.K) ARRIVAL RATE OF FINISHED GOODS (UNITS/WEEK)

A ODOFG.K=TABLE(TODOFG,TIME.K,0,210,70) ORDER DELAY OF FINISHED GOODS (WEEKS)

$\mathrm{T}$ TODOFG=1/.7/.6/.5 TABLE FOR ORDER DELAY OF FINISHED GOODS

NOTE **CONSUMER SUB-SECTION**

R CR.KL=TABLE (TCR,TIME.K,0,210,10) CONSUMPTION RATE (UNITS/WEEK)

T CR=1000/850/700/565/780/1440/1050/1200/1100/810/600/300/400/700/1350/1030/500/600/500/650/470/275

NOTE CONTROL STATEMENT

SAVE GSOR,CR,PR,FINV,IINV,RGSINV,IOR,DINV,DOR

SPEC DT=1/LENGTH=210/SAVPER $=1$

\title{
APPENDIX 2
}

\section{DYNAMO PROGRAMME FOR IMPROVED SYSTEM BEHAVIOUR NOTE INTERLAYER INVENTORY SUB-SECTION}

\author{
L INVOGI.K=INVOGI.J+DT*(IOR.JK-PR.JK) INVENTORY OF GLASSES INTERLAYED (UNITS) \\ $\mathrm{N}$ INVOGI=INVOGII INITIAL INVENTORY FOR INTERLAYED GLASSES (UNITS) \\ C INVOGII $=4500$ \\ A DINVOGI.K=MULT1*SMOOTH(PR.KL,S1) DESIRED INVENTORY OF GLASSES INTERLAYED (UNITS) \\ C MULT1=19.6 INVENTORY MULTIPLIER FACTOR (DIMENSIONLESS) \\ C $\quad$ S1 $=5$ SMOOTHING RANGE (DIMENSIONLESS) \\ C PTIIR $=150$ PRODUCTION TO INTERLAYER INVENTORY RATIO (DIMENSIONLESS) \\ A IINV.K=INVOGI.K/PTIIR INTERLAYER RAW MATERIAL INVENTORY (UNITS) \\ R IOR.KL=MAX(IGDISCR.K/IOT.K,0) INTERLAYER ORDERING RATE (UNITS/WEEK) \\ A IOT.K=TABLE(TIOT,TIME.K,0,210,15) INTERLAYER ORDERING TIME (WEEKS) \\ T TIOT $=16 / 3 / 6 / 10 / 12 / 17 / 14 / 10 / 12 / 14 / 19 / 4 / 8 / 10 / 12$ \\ A IGDISCR.K=DINVOGI.K-INVOGI.K INTERLAYED GLASSES DISCREPANCY (UNITS) \\ NOTE **GLASS SHEET SUB-SECTION** \\ L PGSINV.K=PGSINV.J+DT*(AROGS.JK-PR.JK) PROCESSED GLASS SHEET INVENTORY (UNITS) \\ N PGSINV=PGSINVI \\ C PGSINVI $=4800$ \\ A PGSDINV.K=MULT2*SMOOTH(PR.KL,S2) GLASS SHEET DESIRED INVENTORY (UNITS) \\ C MULT2=17.4 INVENTORY MULTIPLIER FACTOR (DIMENSIONLESS) \\ C S2 $=5$ SMOOTHING RANGE (DIMENSIONLESS) \\ C PTGSIR=3 PRODUCTION TO GLASS SHEET INVENTORY RATIO (DIMENSIONLESS) \\ A RGSINV.K=PGSINV.K/PTGSIR RAW GLASS SHEET INVENTORY (UNITS) \\ R GSOR.KL=MAX(PGSDSCR.K/GSOT.K,0) GLASS SHEET ORDERING RATE (UNITS/WEEK) \\ A GSOT.K=TABLE(TGSOT,TIME.K,0,210,15) GLASS SHEET ORDERING TIME (WEEKS) \\ T TGSOT $=14 / 2 / 24 / 6 / 6 / 4 / 3 / 4 / 8 / 2 / 5 / 4 / 6 / 11 / 5$ \\ R AROGS.KL=DELAY1(GSOR.KL,DOGS.K) ARRIVAL RATE OF GLASS SHEETS (UNITS/WEEK) \\ A DOGS.K=TABLE(TDOGS,TIME.K,0,210,30) DELAY ORDERING GLASS SHEETS (WEEKS) \\ $\mathrm{T}$ TDOGS $=4 / 3.5 / 3 / 2.5 / 2 / 1.5 / 1.2 / 1 \quad$ TABLE FOR DELAY ORDERING GLASS SHEETS
}


A PGSDSCR.K =PGSDINV.K-PGSINV.K PROCESSED GLASS SHEETS DISCREPANCY (UNITS) NOTE**FINISHED GOODS INVENTORY SUB-SECTION**

L FINV.K=FINV.J+DT*(PR.JK-DOR.JK) FINISHED GOODS INVENTORY (UNITS)

N FINV=FINVI INITIAL FINISHED GOODS INVENTORY (UNITS)

C FINVI $=3000$

A FDISCR.K=DFINV.K-FINV.K FINISHED GOODS DISCREPANCY (UNITS)

C FIAT $=4$ FINISHED GOODS INVENTORY ADJUSTMENT TIME (WEEK)

A DFINV.K=DMULT3*SMOOTH(DOR.KL,S3) DESIRED FINISHED GOODS INVENTORY (UNITS)

C MULT3=6.1 DESIRED INVENTORY MULTIPLIER FACTOR (DIMENSIONLESS)

$\mathrm{S} 3=5 \quad$ SMOOTHING RANGE (DIMENSIONLESS)

R PR.KL=MAX (FDISCR.K/FIAT.K, 0) PRODUCTION RATE (UNITS/WEEK)

NOTE **DISTRIBUTORS`INVENTORY SUB-SECTION**

L DINV.K=DINV.J+DT*(AROFG.JK-CR.JK) DISTRIBUTORS`INVENTORY (UNITS)

N DINV=DINVI DISTRIBUTORS`INITIAL INVENTORY (UNITS)

C DINVI $=5550$

C DOT $=4 \quad$ DISTRIBUTORS` ORDERING TIME (WEEKS)

A DDINV.K=MULT4*SMOOTH (CR.KL,S4) DESIRED DISTRIBUTORS`INVENTORY (UNITS)

C $\mathrm{S} 4=5 \quad$ SMOOTHING RANGE (DIMENSIONLESS)

C MULT4=5.6 DESIRED INVENTORY MULTIPLIER FACTOR (DIMENSIONLESS)

A DDISCR.K=DDINV.K-DINV.K DISTRIBUTORS`DISCREPANCY(UNITS)

R DOR.KL=MAX(DDISCR.K/DOT,0) DISTRIBUTORS`ORDERING RATE (UNITS/WEEK)

$\mathrm{R}$ AROFG.KL=DELAY1(DOR.KL,ODOFG.K) ARRIVAL RATE OF FINISHED GOODS (UNITS/WEEK)

A ODOFG.K=TABLE(TODOFG,TIME.K,0,210,70) ORDER DELAY OF FINISHED GOODS (WEEKS)

T TODOFG $=1 / .7 / .6 / .5$ TABLE FOR ORDER DELAY OF FINISHED GOODS NOTE **CONSUMER SUB-SECTION**

R CR.KL=TABLE(TCR,TIME.K,0,210,10) CONSUMPTION RATE (UNITS/WEEK)

TTCR $=1000 / 850 / 700 / 565 / 780 / 1440 / 1050 / 1200 / 1100 / 810 / 600 / 300 / 400 / 700 / 1350 / 1030 / 500 / 600 / 500 / 650 / 470 / 275$

NOTE CONTROL STATEMENT

SAVE GSOR, CR, PR, FINV, IINV, RGSINV, IOR, DINV, DOR

SPEC DT $=1 /$ LENGTH=210/SAVPER $=1$ 